Teologia i Moralność, Volumen 15(2020), numer 1(27)

doi: 10.14746/tim.2020.27.1.11

ORCID: 0000-0003-0497-7460

\author{
JAN TOMCZYK \\ Uniwersytet im. Adama Mickiewicza w Poznaniu \\ Wydział Teologiczny
}

\title{
Kontrowersje wokół Humanae vitae
}

Powszechny zachwyt światowych mediów spowodowany, m.in.: ekumenicznymi tendencjami, zrezygnowaniem z papieskiej tiary, reformą Kurii Rzymskiej, likwidacją indeksu ksiąg zakazanych czy wymuszeniem na franksistowskiej Hiszpanii przyjęcia ustawy o wolności religijnej. Taki obraz Pawła VI w środkach społecznego przekazu można było obserwować od początku jego pontyfikatu. Medialna adoracja odwróciła się o 180 stopni, 25 lipca 1968 roku. Tego dnia papież opublikował encyklikę Humanae vitae, będącą tamą przeciw tętniącej w Europie nieposkromionej fali rewolucji seksualnej. Natychmiast postępowy i reformatorski Pontifex Maximus stał się zacofanym, oderwanym od rzeczywistości starcem forsującym za wszelką cenę anachroniczną, skostniałą doktrynę Kościoła Katolickiego. Aby poznać, jak do tego doszło, trzeba najpierw przyjrzeć się okresowi poprzedzającemu wydanie „encykliki o pigułce”.

\section{Przyczyny zamętu}

\subsection{Maltuzjanizm}

Pierwsze postulaty domagające się kontroli poczęć - które były jednym z powodów napisania Humanae vitae - znajdujemy na przełomie XVIII i XIX wieku, kiedy anglikański pastor Thomas Robert Malthus sformułował tezę, którą nazwał „prawem ludności” (Malthus 2007). Fundamentalne twierdzenie społecznego dogmatu skonstruowanego przez angielskiego duchownego, jest następujące: w związku z intensywnym przyrostem liczby ludności musi dojść do klęski głodu, ponieważ ludzie nie będą w stanie nadążyć z wytwarzaniem 
żywności dla tak wielkiej populacji. Malthus widzi w tym zagrożenie dla dobrobytu i siły klasy panującej. Ludzkość niezaliczającą się do wyższej „kasty” definiuje jako „darmozjadów”, którzy kwalifikują się do eliminacji, ponieważ nie są osobami wytwarzającymi dobrobyt twórczą siłą własnego umysłu i rąk (Kuby 2013, s. 31). „Człowiek, który rodzi się w już zajętym świecie, gdy jego rodzina nie ma środków na wyżywienie go albo gdy społeczeństwo nie potrzebuje jego pracy, nie ma najmniejszego prawa wymagać jakiegokolwiek pożywienia; jest on w ścisłym znaczeniu nadliczbowy w świecie. Na wielkiej uczcie przyrody nie przygotowano dla niego absolutnie żadnego nakrycia. Przyroda każe mu odejść i nie ociąga się z wyegzekwowaniem tego polecenia"1.

Idee Malthusa powróciły w XX wieku, kiedy zapanował strach przed „bombą demograficzną”. Lęk ten był podsycany przez różnego rodzaju publikacje, takie jak np. The Population Bomb Paula Ehrlicha, w której autor snuje apokaliptyczną wizję braku żywności dla ludzkości, która ma się zrealizować w najbliższym czasie. Innym przykładem jest książka Granice wzrostu wydana przez Klub Rzymski w 1972 roku, gdzie autorzy kreują wizję wyczerpania się do nowego milenium surowców mineralnych i zasobów ropy, co miałoby być spowodowane intensywnym zwiększeniem liczby ludności (Kuby 2013, s. 32).

Problem ten został dostrzeżony przez Sobór Watykański II, który w konstytucji Gaudium et spes w rozdziale poświęconym zagadnieniom godności małżeństwa i rodziny zwraca uwagę na to, że „w pewnych wreszcie częściach świata nie bez troski rozważa się problemy powstałe w związku ze wzrostem demograficznym" (GS, nr 47). Warto zauważyć, że idee maltuzjańskie były intencjonalnie rozdmuchiwane $\mathrm{w}$ środkach masowego przekazu, aby przez to sterować rozwojem społecznym. Do tego zagadnienia powrócimy jednak w dalszej części tekstu.

\subsection{Antykoncepcja}

Na początku XX wieku rozpętała się światowa dyskusja o dopuszczalności regulowania poczęć, co dalej rozciągnęło się na zagadnienie antykoncepcji i moralny charakter jej stosowania. Problem ten pojawił się pod wpływem odkryć związanych z lepszym poznaniem cyklu płodności kobiety. W późniejszym czasie odkryto hamujący wpływ progesteronu na proces owulacji (1944), co dało podwaliny do późniejszego rozwinięcia techniki antykoncepcji hormonalnej. Rozwój tej metody osiągnął wkrótce zawrotne tempo. W 1951 roku Goodwin Pincus sporządził skład pierwszego środka antykoncepcyjne-

\footnotetext{
${ }^{1}$ https://de.wikipedia.org/wiki/Thomas_Robert_Malthus [dostęp: 26.02.2018].
} 
go, a już osiem lat później w USA wprowadzono do sprzedaży pierwszy środek hormonalny - Enovid. Symultanicznie firmy farmakologiczne prowadziły badania nad poprawieniem tych „leków” pod kątem niezawodności, łatwości i wygody użycia (Wróbel 2008, s. 82). To ,antykoncepcyjne bum” osiągnęło swój szczyt. Środki blokujące poczęcie stały się powszechnie dostępne we wszystkich krajach europejskich, powstały organizacje propagujące kontrolę urodzin, zainspirowane ideami Malthusa (Noonan 1965, s. 406-407).

Temat antykoncepcji, który zaistniał w tym czasie, nie był notabene zagadnieniem nowym. Najstarsze informacje o stosowaniu antykoncepcji datowane są na lata 1900 do 1100 a. Chr., w egipskich papirusach bowiem możemy znaleźć informacje o umieszczaniu różnych substancji w pochwie kobiety, aby uniknąć niechcianej ciąży. Następnie na przestrzeni wieków wachlarz tych technik się poszerzał (Kupczak 2015, s. 38).

Stosunek Kościoła to tego rodzaju postępowania wyklarował się bardzo wcześnie, bo już w III wieku, kiedy anonimowy chrześcijański teolog w traktacie Odrzucenie wszystkich herezji oskarżył papieża Kaliksta o sprzyjanie antykoncepcji. Dalej przez wieki stanowisko to nie zmieniało się: „,nauczyciele Kościoła nauczali bez wątpliwości czy zróżnicowania, że akty zapobiegające poczęciu są grzechem ciężkim. Żaden katolicki teolog nigdy nie nauczał: «Antykoncepcja jest dobrym czynem». Nauczanie na temat antykoncepcji jest jasne i wydaje się ustalone na zawsze” (Noonan 1965, s. 6). To „wydaje się" w tym tekście jest znamienne, gdyż monolit jednoznacznego potępienia antykoncepcji przez chrześcijaństwo rozpadł się w pierwszej połowie XX wieku.

\subsection{Konferencja w Lambeth}

W 1930 roku na konferencji biskupów Kościoła anglikańskiego w Lambeth przyjęto rezolucję stosunkiem głosów 193 do 67 (przy 47 wstrzymujących się), która umożliwiała ograniczenie lub uniknięcie rodzicielstwa przy dowolności zastosowania metody, o wyborze tejże techniki miały decydować zasady chrześcijańskie. Oczywiście tego typu działanie mogło być podjęte wyłącznie przy wyraźnym, odczuwalnym moralnym zobowiązaniu do zaniechania rodzicielstwa. Należy tutaj podkreślić, że nie było to pozwolenie explicite na antykoncepcję, ponieważ pierwszorzędnie biskupi podali okresową wstrzemięźliwość od współżycia jako formę uniknięcia ciąży, dostrzegli także niebezpieczeństwo związane z powszechną kontrolą urodzeń oraz podkreślili, że podstawowym celem współżycia małżeńskiego jest spłodzenie dzieci.

Hierarchowie Kościoła anglikańskiego wyraźnie potępili stosowanie antykoncepcji z powodu egoizmu i wygodnictwa. Jednocześnie zauważyli, że nauczanie katolickie nie uwzględniało sytuacji, w których pozostanie przy dotych- 
czasowych zasadach doktrynalnych traktujących o zakazie nienaturalnych metod zapobiegania ciąży jest niemożliwe. Nie podali jednak konkretnych okoliczności, które faktycznie miałyby uniemożliwiać pozostanie w zgodzie z dotychczasową wykładnią Kościoła w kwestii antykoncepcji. Przyzwolenie na stosowanie nienaturalnych metod zapobiegania ciąży przez hierarchów anglikańskich, chociaż możliwe tylko w wyjątkowych sytuacjach, było pierwszym przewróconym klockiem domina, które pociągnęło za sobą dalszą lawinę rozmycia dotychczasowego nauczania etycznego we wspólnotach chrześcijańskich. Po anglikanach na antykoncepcję otworzyli się inni protestanci. Dalsza fala moralnego domina doprowadziła w tych wspólnotach in spe do dopuszczenia aborcji, czy możliwości eksperymentowania na ludzkich embrionach (Tabor 2018).

Odpowiedź Kościoła katolickiego była natychmiastowa. Jeszcze tego samego roku papież Pius XI wydał encyklikę Casti connubii, w której zawarł swoistą apologię chrześcijańskiego małżeństwa i dotychczasowej katolickiej nauki moralnej w dziedzinie antykoncepcji. Cała encyklika jest napisana w bardzo podniosłym stylu, a odpowiedź na zmiany przeprowadzone przez Kościół anglikański ogniskuje się w słowach: „Ponieważ od niedawna niejedni, jawnie odstępując od nauki chrześcijańskiej, przekazanej od początku i niezłomnie zachowanej, sądzili że w obecnych czasach inną w tym przedmiocie należy głosić naukę, dlatego Kościół Katolicki, któremu sam Bóg powierzył zadanie nauczania i bronienia czystości i uczciwości obyczajów, Kościół ten, pragnąc pośród tego rozprężenia obyczajów zachować związek małżeński czystym i od tej zakały wolnym, odzywa się przez usta Nasze głośno i obwieszcza na nowo: Ktokolwiek użyje małżeństwa w ten sposób, by umyślnie udaremnić naturalną siłę rozrodczą, łamie prawo Boże oraz prawo przyrodzone i obciąża sumienie swoim grzechem ciężkim" (CC, nr 56).

Papieski dokument daje odpór obecnym tendencjom par excellence przez użycie wielu autorytatywnych zwrotów podkreślających ważność tematu i niezmienności katolickiego nauczania w dziedzinie moralności. Niestety encyklika nie zahamowała rozpędzonego już procesu zaplanowanej, odgórnej popularyzacji technik antykoncepcyjnych.

\subsection{Rockefeller}

W 1952 roku John D. Rockefeller III, amerykański miliarder i „filantrop”, założył w Nowym Jorku „Radę ds. Zaludnienia” („Population Council”), której celem było zrozumienie „zagadnień populacyjnych” (Population Council $2020)^{2}$. Od początku tej organizacji przyświecała wizja jej założyciela, czy-

${ }^{2}$ https://www.popcouncil.org/about/timeline [dostęp: 28.05.2020]. 
li promowanie antykoncepcji jako remedium na „bombę demograficzną”. Po licznych sukcesach w rozpowszechnianiu idei eugenicznych w Stanach Zjednoczonych Rockefeller postanowił podjąć próbę podobnego oddziaływania na terenie Europy. Starał się więc wywrzeć presję na Pawle VI jeszcze przed opublikowaniem przez niego encykliki Humanae vitae. W tym celu udał się do Rzymu, gdzie w lipcu 1965 roku udało mu się spotkać z papieżem. Jednak rozmowa ta nie przyniosła pożądanego, przez amerykańskiego bogacza, skutku (Jones 2013, s. 509).

Rockefeller nie dał jednak za wygraną i następnego dnia wystosował do papieża list, w którym wyłożył swoją wizję przełomowego wpływu stosowania przez kobiety wkładek domacicznych, co - jego zdaniem - wywoła powszechną akceptację wśród ludzi. Sugerował tym jednocześnie słuszność uznania przez Kościół tego środka kontroli urodzin (Jones 2013, s. 510). Snując dalej krajobraz ,antykoncepcyjnego" świata, Rockefeller próbował wymusić na Pawle VI decyzję aprobującą jego postulaty. „Moim zdaniem, jeżeli Kościół nie obejmie w tej sprawie przewodnictwa, będzie to miało dwie konsekwencje: po pierwsze, obecne, coraz silniejsze dążenie ku stabilizacji populacji będzie postępowało, obejmowało kraj po kraju, bez całościowego nadzoru i ukierunkowania, zwłaszcza w sferze moralnej; po drugie jeśli wolno mi to powiedzieć otwarcie, Kościół nie będzie miał udziału w sprawie o fundamentalnym znaczeniu dla jego członków i dla dobra całej ludzkości. Fali powodziowej nie można zatrzymać ani spowolnić, można nią jednak pokierować. Ponieważ gorąco wierzę w doniosłość roli, którą Kościół ma do odegrania w dzisiejszym, niespokojnym świecie, jestem głęboko zatroskany, patrząc na rozwój sytuacji, która w dłuższej perspektywie, jak sądzę, przyniesie szkodę pozycji Kościoła na całym świecie" (Jones 2013, s. 510). Historia pokazuje, że Paweł VI nie ugiął się pod tymi naciskami. Jednak rewolucja seksualna postępowała dalej, aż doszła do swojego punktu kulminacyjnego w 1968 roku.

\subsection{Rewolucja seksualna 1968 roku}

Sfera seksualna człowieka w drugiej połowie XX wieku uległa znacznemu przewartościowaniu. Według wielu osób tamtych czasów to ta płaszczyzna powinna porządkować życie, jednak sama nie powinna dać się zorganizować. Postulowano swobodne poddawanie się sferze seksualnej, przy jednoczesnym zakazie jej blokowania. Idea całkowitego rozluźnienia seksualnego wzięła swój początek w myśli niemieckiego filozofa Herberta Marcusego, który w książce Struktura popędu i społeczeństwo zmodyfikował tezy postawione przez Freuda. W wizji psychoanalizy człowiek jest poddany swoim popędom: popędowi seksualnemu (eros) i śmierci (thanatos). Poprzez sublimację popę- 
du seksualnego człowiek tworzy kulturę, sztukę, urzeczywistnia szeroko rozumiane piękno. U Marcusego w tym miejscu następuje zwrot. Wzywał on do wyzwolenia siły kumulowanej w erosie, postulował życie tu i teraz w całkowitej wolności seksualnej, dyktowanej przez moralność libido. Pod wpływem idei niemieckiego myśliciela propagowano zupełnie wolne pożycie seksualne, bez tabu kazirodztwa, odmienności płci czy nawet wieku (sic!). Chciano zniszczyć rodzinę, ponieważ w Niemczech uważano ją za szkołę autorytarnego charakteru Niemców - bezpośredniej przyczyny Holocaustu (Kuby 2013, s. 59-60).

„Antychrześcijańska rewolucja antropologiczna” (Bartkowicz 2008, s. 9) przeniosła się następnie do środowiska uniwersyteckiego, gdzie spowodowała wielkie zamieszanie. Przykładowo, paryscy studenci przejmowali katedry profesorskie, uniwersytety stawały się miejscami pijatyk, chodzono nago po terenach akademickich, by w ten sposób zamanifestować wolność seksualną. $\mathrm{W}$ wielkich europejskich miastach organizowano marsze, podczas których padały hasła inspirowane myślami Marksa, Marcusego i Mao-Tse Tunga: „Kto śpi dwa razy z tą samą (tym samym) należy do establishmentu!”, „Zakazuje nam się zakazywać!”, „Wykończcie to, co was wykańcza!”, „Wypowiedzmy wojnę mieszczańskiej rodzince!” (Kuby 2013, s. 58). „Rewolta studencka 1968 roku sfinalizowała uporczywe, trwające od 200 lat usiłowania wielu wielkich umysłów pragnących doprowadzenia do zawalenia się żydowsko-chrześcijańskiego fundamentu kultury zachodniej. Orędzie "wyzwolenia seksualnego» dotarło do każdego domu i do większości sypialni” (Kuby 2013, s. 61). Wszystkie powyższe wydarzenia miały miejsce na kilka miesięcy przed wydaniem Humanae vitae przez Pawła VI. Wielki pożar antychrześcijańskiej, antynatalistycznej rewolucji dosięgnął także hierarchów Kościoła katolickiego.

\subsection{Komisja, dychotomia i wyciek}

Podczas już trwającego Soboru Watykańskiego II starano się wywrzeć poprzez media jak największy nacisk na obradujących, by doktryna katolicka została złagodzona, zrelatywizowana. Tematem budzącym największe emocje była kwestia unormowania burzy rozpętanej wokół współżycia małżeńskiego i dopuszczalności antykoncepcji. Jan XXIII, świadom delikatności tego tematu i jednocześnie jego wielkiej wagi, powołał w 1963 roku specjalną komisję: „Commissio pro studio populationis, familiae et natalitatis”, której głównym celem było przestudiowanie problemów demograficznych. Informacja o tej instancji szybko obiegła świat i wielu uważało, że została ona powołana głównie $\mathrm{w}$ celu ustalenia, czy katolicy mogą korzystać z antykoncepcji (Weigel 2000, s. 265). Jan XXIII umarł w roku powołania komisji do życia, jednak 
jego następca, Paweł VI podtrzymał jej istnienie oraz w 1964 roku rozszerzył jej skład. Nowo wybrany papież zastrzegł sobie prawo wydania ostatecznego werdyktu w sprawie moralnych wątpliwości związanych z dziedziną regulacji poczęć, a efekt prac komisji miał pozostać tajny, aby uniknąć dziennikarskich sensacji (Paweł VI i in. 1969, 7).

Komisja niestety uległa dychotomii. Większość jej członków postulowała zmianę dotychczasowej teologii moralnej oraz dopuszczenie stosowania środków antykoncepcyjnych (tę podkomisję reprezentowali m.in. A. Auer, R. Sigmung, P. Anciaux, B. Häring), mniejszość natomiast broniła dotychczasowego nauczania Kościoła (J. Ford, J. Visser, M. Zalba, S. De Lestapis, do tej grupy dołączył również K. Wojtyła). Obie podkomisje jako zwieńczenie swoich prac przygotowały oddzielne dokumenty (Wróbel 2008, s. 87).

Presja na papieża została zwiększona najpierw w 1966 roku przez wydanie $\mathrm{w}$ archidiecezji monachijskiej instrukcji sankcjonującej stosowanie antykoncepcji, a następnie poprzez wyciek do prasy amerykańskiej i europejskiej w kwietniu 1967 roku trzech dokumentów spisanych przez członków komisji (Smith 1991, s. 12-13). Tekstem który spowodował największe zamieszanie, był fragment raportu wieńczącego prace komisji, w którym zmiana dotychczasowego nauczania w sprawie antykoncepcji została przegłosowana przez biskupów przewagą dziewięciu głosów nad trzema.

Zamęt wzrósł więc do tego stopnia, że Paweł VI musiał podjąć decyzję, a pomoc $\mathrm{w}$ jej podjęciu miały mu przynieść trzy dokumenty. Pierwszy to tzw. raport większości, w nim znalazły się postulaty zmiany dotychczasowego nauczania Kościoła w dziedzinie teologii moralnej oraz możliwości dopuszczenia antykoncepcji pod pewnymi warunkami. Drugi dokument to tzw. raport mniejszości, w którym zostały odrzucone jakiekolwiek zmiany w katolickiej doktrynie dotyczącej kwestii antykoncepcji. Trzeci dokument przedstawiony przez zwolenników autorów raportu większości był schematem dokumentu, który papież mógłby opublikować (Paweł VI i in. 1969, 7).

Janet E. Smith w swojej książce wyróżnia cztery różnice między dwiema podkomisjami „Commissio pro studio populationis, familiae et natalitatis”. Pierwszą jest rozbieżność oceny historycznej dotyczącej stałości sprzeciwu Kościoła przez wieki wobec praktyk antykoncepcyjnych. Drugą antynomią jest ocena skutków, jakie może za sobą nieść akceptacja antykoncepcji przez Kościół, i wpływu tej decyzji na jego autorytet w dziedzinie moralności. Po trzecie, odmienne zdania dotyczyły sposobu naruszania prawa naturalnego przez antykoncepcję. Brak zgodności ujawnił się również w oszacowaniu konsekwencji w ocenie moralnej innych aktów seksualnych, gdyby Kościół zmienił swoje nauczanie w kwestii antykoncepcji (Smith 1991, s. 14).

Oba dokumenty miały swoje słabe strony. Raport mniejszości miał charakter ściśle apologetyczny, nie wprowadził żadnych nowych argumentacji 
teologicznych, bronił dotychczasowego stanowiska ex auctoritate, ponadto nie wykorzystał argumentacji już wypracowanych na Soborze Watykańskim II. Słabością raportu większości - oprócz błędów teologicznych, które w dalszym tekście zostaną omówione - jest sceptycyzm, niejasne sformułowania, względność zasad moralnych, zbliżanie się do tzw. etyki sytuacyjnej, brak precyzji w formułowaniu ważnych pojęć, mało klarownie jest również przedstawiona relacja między dobrem osoby ludzkiej a dobrem małżeńskim. Dokument opracowany przez podkomisję opowiadającą się za zmianą dotychczasowego nauczania jest swoistą syntezą błędnych tendencji w teologii moralnej, które w ostatnich latach przed Humanae vitae zaczęły dochodzić do głosu (Paweł VI i in. 1969, 7-8).

\subsection{Błędy teologiczne}

Teologowie głoszący tezy sprzeczne z doktryną Kościoła dotyczącą moralności doczekali się odpowiedzi w Humanae vitae. Papież przytacza ich postulaty, a następnie wykazuje w nich niezgodność z nauczaniem Mistycznego Ciała Chrystusa. $Z$ uwagi na rozległość tematu przytoczone zostaną jedynie te błędne opinie teologiczne, które znalazły swój odpór w wyżej wspomnianej encyklice. Jednym z błędów teologicznych, który pojawił się w okresie przed Humanae vitae, to argument postępu technologicznego. Uważano, że skoro człowiek wypracował sobie własnym rozumem techniczną możliwość ingerencji w płodność, to powinno się ją wykorzystać (HV, nr 16). Ta teza była poparta podżeganym lękiem przed „bombą demograficzną”. Błąd tkwił w tym, że rozum nie stwarza reguł moralnych, ale je odczytuje. Kolejny teologiczny postulat dotyczył sytuacji stawania w obliczu dwóch złych możliwości, spośród których należy wybrać tę mniej szkodliwą. Mniejszym złem miało być stosowanie antykoncepcji, a większym niedogodności małżonków związane z koniecznością okresowego powstrzymywania się od współżycia (HV, nr 14). Przez taką hipotezę ipso facto działanie seksualne w małżeństwie stałoby się całkowicie zdeterminowane i bezwzględnie konieczne. Dalej, teologowie przy ocenie aktów seksualnych odwoływali się do źle przez nich zrozumianej zasady całościowości. Błąd teologiczny polegał na traktowaniu prokreacji jako celu odnoszącego się do całości życia małżeńskiego, a nie odwołującego się do poszczególnych aktów (HV, nr 3). Konsekwencją powyższego postulatu jest brak możliwości oceny moralnej poszczególnego aktu małżeńskiego, gdyż możliwa pozostałaby jedynie ocena całości życia małżonków. Ta teza niebezpiecznie zbliża się do zasady „cel uświęca środki”, która jest nie do przyjęcia w etyce chrześcijańskiej (Paweł VI i in. 1969, 24-26). 


\section{Punkt zapalny}

\subsection{Publikacja Humanae vitae}

Paweł VI, w odpowiedzi na pogłębiający się zamęt, wydał długo oczekiwaną encyklikę, poprzez którą postawił tamę rozpędzonej rewolucji seksualnej ogarniającej całą ludzkość. Odwołując się do personalizmu chrześcijańskiego, nakreślił w niej katolicką wizję człowieka, ukazał wielką godność małżeństwa, jego prawa i obowiązki oraz sakramentalny charakter. Potwierdził także dotychczasową naukę Kościoła dotyczącą antykoncepcji. Ponadto zachęcił małżonków do odpowiedzialnego rodzicielstwa, dodając im odwagi w pójściu trudną drogą, prowadzącą ostatecznie do zbawienia (HV, nr 25). Kapłanom przypomniał wielki obowiązek podawania w całości i otwarcie nauki Kościoła o małżeństwie. Upomniał ich także słowami Listu św. Pawła do Koryntian, aby byli jednomyślni i wystrzegali się rozłamów $(1$ Kor 1,10). Zachęcał prezbiterów do towarzyszenia małżonkom, uczenia ich drogi modlitwy i wierności sakramentom (HV, nr. 28-29). Szczególnie wzruszająca jest odezwa papieża do biskupów, znajdująca się w przedostatnim punkcie encykliki. Nieomalże błagał biskupów, by oddali się dziełu troski o małżeństwa, które w tym czasie jest najważniejszym zadaniem do podjęcia (HV, nr 30). Dokument spuentował słowami: „Człowiek bowiem nie zdoła osiągnąć prawdziwego szczęścia, do którego tęskni całą swą istotą, inaczej, jak zachowując prawa, wszczepione w jego naturę przez Najwyższego Boga" (HV, nr 31).

Humanae vitae przez mocne skoncentrowanie się na aktach seksualnych, brak nacisku na godność ludzką i równość małżonków, wystawiło encyklikę na oskarżenia o „,biologizm”, legalizm czy niewrażliwość duszpasterską (Weigel 2000, s. 268-269). Z powodu tętniącej w Europie rewolucji seksualnej George Weigel twierdzi, że „moment pojawienia się Humanae vitae nie mógł być gorszy" (Weigel 2000, s. 269).

\subsection{Kulisy publikacji Humanae vitae}

Paweł VI, nazywany także „papieżem burzliwych czasów”, nie krył ciężaru podjęcia tak trudnej decyzji. „Jeszcze nigdy nie odczuwaliśmy ciężaru naszego urzędu tak bardzo jak w tym przypadku. [...] Jakże często drżeliśmy przed obiema możliwościami: albo wydać pochopnie osąd, który odpowiadałby panującym poglądom, albo taki, który byłby niechętnie przyjęty przez dzisiejsze społeczeństwo i byłby, jako uznany za czysto arbitralny, zbyt trudny dla życia małżeńskiego. Wzywaliśmy Ducha Świętego oraz nieustannie i chętnie nastawialiśmy nasze sumienie na głos prawdy. I nie pozostała nam żadna 
wątpliwość, że naszym obowiązkiem jest wyrażenie naszej decyzji w określonym ujęciu tej encykliki” (Paweł VI 1968 a). Powyższe słowa, wypowiedziane sześć dni po publikacji Humanae vitae, pomagają nam poznać rozwagę Pawła VI w podjęciu decyzji o wydaniu ,encykliki o pigułce”.

Kardynał Ratzinger podczas jednej ze swoich homilii cytuje osobistą wypowiedź Pawła VI, która rzuca jeszcze większe światło na decyzję papieża: „Była to bardzo trudna decyzja, decyzja, o której wiedziałem, że była przeciwna oczekiwaniom chrześcijaństwa, którą jednak coram Domino, przed obliczem Pana, z bólem podjąłem" (Ratzinger 1978, 336). Ta decyzja pociągnęła za sobą falę krytyki, która okazała się rewolucyjną hydrą o głowach kleru, teologów i laikatu.

\section{Konsekwencje}

\subsection{Bunt duchowieństwa}

Już 30 sierpnia 1968 roku, dwa miesiące po opublikowaniu Humanae vitae, Episkopat Niemiec wydał Deklarację z Königstein, w której stwierdzono, że wyżej wspomniana encyklika nie spełnia wymogów papieskiej nieomylności, zatem biskupi dali wiernym wolną rękę w korzystaniu $\mathrm{z}$ antykoncepcji. Natychmiastowo biskupi dostali silne wsparcie katolików, którzy na corocznym Katholikentagu w Essen przyjęli uchwałę stosunkiem głosów 50000 do 90, w której zażądali od Pawła VI zmiany encykliki. Dwa miesiące później Episkopat Austrii przyjął Deklarację z Maria Trost, która wyjmowała antykoncepcję spod osądu Kościoła, taką samą decyzję podjęli w 1972 roku biskupi szwajcarscy (Górny 2015, s. 137). Wspólnym mianownikiem tych stanowisk było przyznanie wierzącym możliwości wyrobienia sobie opinii innej niż papieskiej i życia w zgodzie ze swoim sumieniem. Biskupi jakby nie dopuścili pod rozwagę błędnie uformowanego sumienia katolika wydającego sąd sprzeczny z przyjętą doktryną katolicką (Laun 2008, s. 144).

Prymas Holandii, kard. Alfrink, stwierdził, że encykliki nigdy nie są nieomylne, a najważniejszą normą pozostaje sumienie. Ten hierarcha w 1969 roku razem z setką księży i ośmioma biskupami ogłosił Deklarację Niepodległości, w której wzywał holenderskich katolików do odrzucenia Humanae vitae. Szczególnie dotkliwym dla Pawła VI ciosem był sprzeciw prymasa Belgii, kard. Léona-Josepha Suenensa, jego osobistego przyjaciela. Wypowiedział on posłuszeństwo papieżowi i oskarżał go o lekceważenie zasady kolegialności w Kościele z powodu przesadnego przywiązania do papieskiego autorytetu (Górny 2015, s. 137). Również niższy kler buntował się przeciwko papieskiej 
encyklice. W sierpniu 1968 roku w katedrze Santiago de Chile ośmiu księży zabarykadowało się i przez 14 godzin okupowało ten kościół, sprzeciwiając się w ten sposób podróży Pawła VI do Kolumbii (Górny 2015, s. 136).

\subsection{Bunt teologów}

Kilka miesięcy po publikacji Humanae vitae, 7 grudnia 1968 roku, papież tak oceniał obecną sytuację Kościoła: „W Kościele wybiła niespokojna godzina samokrytyki, a raczej należałoby powiedzieć samodestrukcji. To karkołomny zwrot, którego po Soborze nikt by się nie spodziewał. Wygląda na to, jak gdyby Kościół sam sobie zadawał rany" (Paweł 1968b). Te ciosy przyszły również ze strony katolickich myślicieli. Atak rozpoczął się wraz z powstaniem tzw. Deklaracji kolońskiej, w której teologowie, nawiązując do nauki Pawła VI dotyczącej regulacji poczęć, zaatakowali go wprost i podważyli prawo papieża to sprawowania urzędu nauczycielskiego (Laun 1998, s. 366-367).

Joseph Gallagher, thumacz Soboru Watykańskiego II i profesor filozofii tomistycznej, zrezygnował z przyznanego mu tytułu prałata, ponieważ ta godność zobowiązywała go do specjalnej wierności papieżowi, natomiast encyklika, którą uważał za „tragiczną i przerażającą”, nie pozwalała mu na bycie dalej wiernym następcy Piotra. Uważał, że akceptacja tego dokumentu równałaby się przyzwoleniu na logikę inkwizycji i praktykowania tortur (Górny 2015, s. 136). Przeciwny encyklice był także Bernhard Häring, który uważał, że Humanae vitae odeszła od zasad Soboru Watykańskiego II i nie może ona być ostatnim słowem Kościoła (Paweł VI i in. 1969, 35).

Błędne tezy teologiczne przedostały się także do komunistycznej Polski. W miesięczniku „Więź”, w styczniu 1969 roku, opublikowano artykuł Karla Rahnera SJ, w którym kontestował niezmienność nauki podanej przez Pawła VI w Humanae vitae. Jezuita implicite starał się wykazać możliwość zmiany stanowiska Kościoła i przez cały swój artykuł ukazywał słabości encykliki, nie starając się podjąć polemiki z argumentacją papieża. „Chcemy jedynie pokazać, iż poza teoretyczną możliwością niezawinionego błędu sumienia istnieją również racje, dla których w tym konkretnym przypadku również w sumieniu autentycznie katolickim można by w sposób psychologicznie zrozumiały dojść do (subiektywnego) przekonania, że nie jest się związanym z papieską normą" (Rahner 1969, s. 43). Warto tutaj zaznaczyć, że błędne tezy teologiczne nie były jakimś „koniem trojańskim” mającym zniszczyć od środka Kościół. Ksiądz profesor Tadeusz Styczeń podkreśla dobrą wiarę teologów, którzy chcieli wyjść naprzeciw ludzkiej słabości i przez to dokonać antropocentryzmu w teologii moralnej. Wyżej wspomniani teologowie kierowali się 
chęcią pomocy ludziom i sądzili, że będą mogli im ją nieść przez uprawomocnienie antykoncepcji. Ta droga pozostawienia wolności wyboru człowiekowi w dziedzinie współżycia bez stawiania mu jasnych granic prawa Bożego niosła za sobą poważne konsekwencje (Rozmowa z ks. prof. Styczniem 2003, s. 508).

\subsection{Bunt laikatu}

Pod wpływem zamieszania wśród duchownych wierni świeccy przejęli od swoich pasterzy „chorobę” nieposłuszeństwa względem Pawła VI. Powstała tak zwana „,inicjatywa ludu Bożego”. Chciano stworzyć nowy obraz Kościoła z nowym rozumieniem jego nauczania. Ten czas charakteryzują „listy trzody”, czyli postulaty utworzenia nowego autorytetu w Kościele (Laun 1998, s. 367). W sierpniu 1968 roku w australijskim mieście Adelaide przed katedrą zgromadzili się studenci, którzy przez transparenty, okrzyki i ulotki nawoływali do obrony antykoncepcji. Legitymowali się oni jako „Katolickie Centrum Poparcia Antykoncepcji” (Górny 2015, s. 136). Na tego typu tendencje Paweł VI odpowiedział jasno: „Nikt na przykład nie może pragnąć nowości tam, gdzie byłaby ona zdradą wiary; wiary nie można wymyślić, nie wolno nią dowolnie kierować; wiara jest darem, należy jej strzec i nią żyć. Inne rozumowanie może nas doprowadzić do naruszenia wspólnoty kościelnej. [...] Kościół zawsze jest jeden, wspólny, hierarchiczny i jednomyślny. Takim właśnie uczynił go Chrystus, a tradycja apostolska przyczyniła się do jego rozwoju: «Ja jestem prawdziwym krzewem winnym - powiedział Chrystus - wy latoroślami». Nie zapomnimy nigdy tego zadziwiającego obrazu ewangelicznego. Gałęzie krzewu winnego muszą być podcinane; gdy bowiem odetniemy gałęzie nie przynoszące owocu, inne będą obficiej owocować. Nowość dla samej nowości nie może znaleźć usprawiedliwienia, zwłaszcza gdy poczynimy ustępstwa na rzecz charakterystycznych pokus naszych czasów skłonnych do całkowitego obalenia tradycji, historii i doświadczenia, poprzez które otrzymaliśmy Dobrą Nowinę i dzięki którym istnieje dziś Kościół. Może niektórzy chcieliby zapomnieć o przejętej od przodków spuściźnie, a wychodząc od punktu zerowego, stworzyć na swój sposób Kościół zupełnie nowy i dostosowany do własnych upodobań” (Paweł VI 1971).

\section{Eksurs. Walka Kościoła z zamętem antynatalistycznym}

Podczas trwającej wewnątrz Kościoła burzy nie zabrakło również słów wdzięczności kierowanych w stronę Pawła VI po opublikowaniu Humanae vi- 
tae. „Encyklika jest najpiękniejszym błogosławieństwem, jakie przychodzi do ludzkości od Kościoła po Soborze. Wśród cierpień i goryczy wojny wierni mojej diecezji i ja sam, przyjęliśmy wiadomość o encyklice z radością i ulgą" (Paweł VI $i$ in. 1969, 4), mówił biskup Jan Okoye z Nigerii. Nie był to jednak osamotniony głos. W swoim komentarzu do powyższej encykliki polscy teologowie przytoczyli także kolejne podziękowania płynące od katolików z Afryki: „Problem zapóźnienia w rozwoju gospodarczym jest problemem ludzkim, moralnym, nie tylko ekonomicznym, materialnym. Zdaje się, że tylko Papież dobrze to rozumie. On, który poucza o integralnym rozwoju człowieka [...] Dla nas, murzynów afrykańskich, życie jest podwójnie święte" (Paweł VI i in. 1969, 4).

Często cytowani w wielu miejscach tego artykułu, polscy teologowie (ks. Jerzy Bajda, o. Karol Meissner OSB, ks. Stanisław Smoleński, ks. Tadeusz Ślipko SJ, ks. Juliusz Turowicz) pod przewodnictwem abp. Karola Wojtyły, dali duże wsparcie Pawłowi VI, wysyłając mu tzw. Memoriał krakowski, w którym przedstawili personalistyczną wizję człowieka i jego seksualności, aby przez to bronić dotychczasowej doktryny moralnej Kościoła. Nieśli pomoc papieżowi także przez napisanie wprowadzenia i komentarzy do Humanae vitae oraz przez odpieranie błędnych teologicznych tez, pojawiających się przed opublikowaniem wcześniej wspomnianej encykliki i potem (Wojtyła $i$ in. 1969, s. 194-371).

Dalszą recepcję encykliki Humanae vitae i obronę dotychczasowej katolickiej teologii moralnej przyniósł pontyfikat św. Jana Pawła II. Już u samego początku swojego pontyfikatu podkreślał zasługi Pawła VI: „Stał się apostołem Ukrzyżowanego, podobnie jak św. Paweł. Wiedział, co to zniewagi, opluwanie, smutek i udręka. Znosił przeciwności dzięki modlitwie i niezachwianej wierze. Na próby pochodzące z wewnątrz i zewnątrz Kościoła odpowiadał niezłomną wiarą, nadzieją i miłością, które sprawiły, że stał się Piotrem naszych czasów" (Górny 2015, s. 139). W tym miejscu można wymienić szereg katechez św. Jana Pawła II „Mężczyzną i niewiastą stworzył ich...”, które były komentarzami do encykliki Pawła VI. Dalszy wkład przyniosła adhortacja apostolska Familiaris consortio, list apostolski Mulieris dignitatem, list do rodzin Gratissimam sane oraz aktualizacja Humanae vitae w encyklice Evangelium vitae. Szczególną odpowiedzią na zamęt w teologii moralnej była encyklika Veritatis splendor. Kolejni papieże również odnosili się do encykliki Humanae vitae i w ten sposób potwierdzali jej aktualność ${ }^{3}$.

$$
* * *
$$

${ }^{3} \mathrm{Na}$ temat aktualizowania treści Humanae vitae, w nauczaniu ostatnich papieży zob.np.: (Benedykt 2009, 15; AL, nr 80; 154). 
Ponowna recepcja Humanae vitae i odczytanie jej profetycznego charakteru jest szczególnie potrzebne w dzisiejszych czasach, kiedy można dostrzec wiele ataków skierowanych przeciwko rodzinie, przeciwko małżeństwu. Podobnie jak w czasach Pawła VI, obrona tez zawartych w jego encyklice nie stała się łatwiejsza, ale urosła do rangi zupełnego anachronizmu i symbolu skostnienia Kościoła katolickiego. Mimo to, nadal z niezachwianą pewnością, należy bronić tego dokumentu, posługując się doskonalszą retoryką i zręczniejszymi argumentami wypracowanymi przez katolickich teologów w ciągu pięćdziesięciu lat od wydania Humanae vitae.

Znaczenie tego tematu podkreślił w 2008 roku kardynał Christoph Schönborn: „Chodzi o przyszłość Europy. W ciągu czterdziestu lat powiedziała trzykrotnie «nie» swojej przyszłości: w 1968 roku, odrzucając encyklikę Pawła VI Humanae vitae, kilka lat później legalizacją przerywania ciąży, wprowadzoną w większości krajów europejskich, i ostatnio za zgodą na «homomałżeństwa»" (Kuby 2013, s. 67). Warto w tym miejscu wspomnieć o subtelnej zmianie poglądu kard. Schönborna na związki osób tej samej płci. W wywiadzie udzielonym dla włoskiego czasopisma „Civilta Cattolica”, metropolita Wiednia sugeruje, aby w związkach między homoseksualistami dostrzegać pewne elementy małżeństwa. Powołuje się w tym miejscu na nauczanie Soboru Watykańskiego II, który we wspólnotach niekatolickich dostrzegł elementy Kościoła. Schönborn wspomina w powyższym wywiadzie, że zawarcie związku między osobami tej samej płci może być korzystne w porównaniu do sytuacji, kiedy ktoś ciągle zmienia swoich partnerów. Kardynał ponadto domaga się poszanowania takich związków, choć jednocześnie zaznacza, że nie można nazwać ich małżeństwami (Idziemy 2015) ${ }^{4}$.

Choć w jednej z trzech kwestii, poruszonych przez kard. Schönborna w Jerozolimie, zdaje się on sam nieco zmieniać własne zdanie, to jednak znani są inni kardynałowie, którzy w kwestii antykoncepcji dołączyli się do silnego społecznego „nie” wobec dotychczasowej nauki Kościoła, a nawet sugerowali przeprosiny za publikację Humanae vitae (Wiśniewska 2008) ${ }^{5}$. Spór o „encyklikę o pigułce" trwa zatem nadal, a dramat dzisiejszej Europy tylko się pogłębia. Zdaje się, że ten stan nie ulegnie zmianie, dopóki nie zostanie usłyszany i przyjęty cichy, proroczy głos, płynący z zaledwie kilkunastu stron Humanae vitae.

${ }^{4} \mathrm{http} / /$ www.idziemy.pl/kosciol/kard-schoenborn-broni-tez-odrzuconych-przez-synod/ [dostęp: 28.05.2020].

${ }^{5}$ https://wyborcza.pl/1,75399,5770016,Kosciol_spiera_sie_o_antykoncepcje.html [dostęp: 28.05. 2020]. 


\title{
CONTROVERSIES AROUND HUMANAE VITAE
}

\section{Summary}

The purpose of the text is to present a list of controversies that took place at the time of publication of encyclical Humanae Vitae, written by pope Paul VI. First, through presentation of the historical background, the text shows the reasons of difficult reception of papal document. Further, the text presents the backstage of the sheer promulgation of the encyclical by the pope. Next, the objection to the document by the clergy, theologians, and laity is shown, followed by the examples of positive reactions to Humanae Vitae. The author presents also current difficulties in reception of the message of the encyclical and highlights its lasting relevance.

Keywords: Humanae vitae; Paul VI; contraception; sexual revolution; split in Church

Słowa kluczowe: Humanae vitae; Paweł VI; antykoncepcja; rewolucja seksualna; rozłam w Kościele

\section{WYKAZ SKRÓTÓW}

\author{
AL - Franciszek, Adhortacja Amoris laetitia \\ CC - Pius XI, Encyklika Casti connubii \\ CV - Benedykt XVI, Encyklika Caritas in veritate \\ GS - Sobór Watykański II (1965), Konstytucja duszpasterska o Kościele w świecie wspótczesnym \\ „, Gaudium et spes". \\ HV - Paweł VI, Encyklika Humanae vitae
}

\section{BIBLIOGRAFIA}

Bartkowicz W. (2008), Próba oceny dyskusji wokót «Humanae vitae», „Teologia i Moralność” 3, s. 7-17.

Benedykt XVI (2009), Encyklika Caritas in veritate.

Franciszek (2016), Adhortacja Amoris laetitia.

Górny G. (2015), Atak na Pawła VI, „Pastores” 66(1), s. 133-139.

Jones E.M. (2013), Libido dominandi. Seks jako narzędzie kontroli społecznej, Wrocław.

Kuby G. (2013), Globalna rewolucja seksualna, Kraków.

Kupczak J. (2015), «Znak, któremu sprzeciwiać się będą» (Łk 2,34). O proroczym znaczeniu encykliki Humanae vitae, „Warszawskie Studia Teologiczne” 28(3), s. 36-64.

Laun A. (1998), Trzydzieści lat po Humanae vitae, „Ethos” 43(3), s. 365-371.

Laun A. (2008), «Humanae vitae» - niepotrzebny ciężar czy źródlo miłości??, „Ethos” 84(4), s. 142-147 .

Malthus Th.R. (2007), Prawo ludności, Warszawa.

Noonan J.Th. (1965), Contraception: A History of Its Treatment by the Catholic Theologians and Canonists, Massachusetts: Harvard University Press Cambridge. 
Paweł VI (1968a), Przemówienie podczas audiencji generalnej 31 lipca 1968 roku.

Paweł VI (1968b), Przemówienie w Papieskim Seminarium Lombardzkim w Rzymie 7 grudnia 1968 roku.

Paweł VI (1968), Encyklika Humanae vitae.

Paweł VI (1971), Przemówienie podczas audiencji generalnej 4 sierpnia 1971 roku.

Pius XI (1930), Encyklika Casti connubii.

Rahner K. (1969), Na marginesie encykliki «Humanae vitae», „Więź” 129(1), s. 35-53.

Ratzinger J. (1978), Homilia w monachijskiej Liebfrauenhirche, w: J. Szymik (2016), Theologia Benedicta, t. 3, Katowice, s. 336.

Smith J.E. (1991), Humanae Vitae. A Generation Later, Washington, D.C..

Sobór Watykański II (1965), Konstytucja duszpasterska o Kościele w świecie współczesnym «Gaudium et spes».

W rocznice ogloszenia encykliki «Humanae vitae». Rozmowa z Księdzem Profesorem Tadeuszem Styczniem, (2003), ,Ethos” 63-64(3-4), s. 507-509.

Weigel G. (2000), Świadek nadziei, Kraków.

Wojtyła K. i in. (1969), Memoriat Krakowski oraz wprowadzenie do Humanae vitae, w: Analecta Cracoviensia 1969, red. Karol Wojtyła, Kraków, s. 194-371.

Wróbel J. (2008), Czy obronimy katolicka naukę o moralności matżeńskiej? Refleksje nad aktualnościa przesłania encykliki «Humanae vitae» $w$ czterdziesta rocznice jej ogłoszenia, „Teologia i Moralność" 4, s. 81-105.

\section{Publikacje elektroniczne}

De.wikipedia.org. 2018. Thomas Robert Malthus, https://de.wikipedia.org/wiki/Thomas_Robert_ Malthus [dostęp: 26.02.2018].

Idziemy (2015), Austria: kard. Schönborn broni swoich tez, odrzuconych przez Synod, http://www. idziemy.pl/kosciol/kard-schoenborn-broni-tez-odrzuconych-przez-synod/ [dostęp: 28.05.2020].

Paweł VI i in. (1969), Encyklika Humanae vitae oraz komentarz teologów moralistów środowiska krakowskiego pod kierunkiem Karola kardynała Wojtyly, http://kodr.pl/wp-content/uploads/2017/03/humanae_vitae.pdf [dostęp: 26.02.2018].

Population Council (2020), Timeline, https://www.popcouncil.org/about/timeline [dostęp: 28.05. 2020].

Tabor M. (2018), Konferencja w Lambeth. Co wydarzyło się w roku 1930?, http://npr.pl/index.php/ content/view/277/ [dostęp: 25.02.2018].

Wiśniewska K. (2008), Kościót spiera się o antykoncepcję, https://wyborcza.pl/1,75399,5770016,Ko sciol_spiera_sie_o_antykoncepcje.html [dostęp: 28.05.2020].

JAN ToMczYK - misjonarz Świętej Rodziny, kleryk, student IV roku Wyższego Seminarium Duchownego Zgromadzenia Misjonarzy Świętej Rodziny w Kazimierzu Biskupim, na Wydziale Teologicznym UAM. Interesuje się myślą Josepha Ratzingera; e-mail: janeq.tomczyk@gmail.com. 